\title{
Przestrzeń w wypowiedziach dzieci niewidomych w wieku wczesnoszkolnym
}

\begin{abstract}
Kamila Miler-Zdanowska, Przestrzeń w wypowiedziach dzieci niewidomych $w$ wieku wczesnoszkolnym [Space in the statements of blind children at early school age]. Interdyscyplinarne Konteksty Pedagogiki Specjalnej, nr 20, Poznań 2018. Pp. 251-269. Adam Mickiewicz University Press. ISSN 2300-391X. DOI: 10.14746/ikps.2018.20.13

People with visual disabilities acquire knowledge about the surrounding space using other strategies than sighted people. The final stage of gathering this information is independent movement in space as well as the ability to describe it.The aim of the article is to present ways of experiencing space by blind people and strategies to build mental maps in their minds and to present knowledge about space by creating a description of it.The article also presents the results of research on the description of space by blind children in early school age.
\end{abstract}

KEY WORDS: space, special relations, spatial orientation, visual disability, description of space

Człowiek jest istotą osadzoną w otaczającej go przestrzeni. Jej poznanie i eksplorowanie jest jego nieodłącznym doświadczeniem, którego nie jest zazwyczaj świadomy. Zatem pojęcie

doświadczenie przestrzenne oznacza sposób poznawania i postrzegania przestrzeni a w konsekwencji zespół różnorodnych zachowań 
przestrzennych, takich jak: myślenie o przestrzeni, użytkowanie, budowanie struktur przestrzennych itp. ${ }^{1}$.

W doświadczaniu przestrzeni zasadniczą rolę odgrywają: percepcja przestrzeni (odbiór zmysłowy), procesy poznawcze, zasób pojęć, znajomość schematu ciała, wyobrażenia przestrzenne, wiedza o otoczeniu, operowanie relacjami odległości i czasu². Najlepszym sposobem poznawania otaczającej nas przestrzeni jest poruszanie się w niej. Dzięki takiej aktywności możemy doświadczyć jej całym swoim ciałem, wszystkimi zmysłami. W ten sposób zbieramy informacje, a następnie gromadzimy je w naszej pamięci i tworzymy $\mathrm{z}$ nich strukturę przestrzeni dla danego otoczenia. Zatem najbardziej bezpośrednie informacje o stosunkach przestrzennych zawdzięczamy naszym odczuciom kinestetycznym, jednak proces ten jest czasochłonny. Szybszym sposobem na ocenę przestrzeni jest jej wzrokowe poznanie ${ }^{3}$, które umożliwia nam odbiór kilku informacji jednocześnie. Zdobyte w ten sposób dane możemy wykorzystać do interpretacji odległości i lokalizacji przedmiotów w przestrzeni. Niewątpliwie wzrok pełni bardzo ważną rolę w orientowaniu się w przestrzeni. Jego brak utrudnia jej poznawanie, ale nie powoduje, że proces ten jest niemożliwy.

U osób, które utraciły możliwość widzenia orientowanie się w przestrzeni jest możliwe dzięki sprawnie działającym pozostałym zmysłom. Kluczowe znaczenie ma tu słuch, dotyk, zmysł kinestetyczny, zmysł równowagi oraz zmysł powonienia 4 . Bardzo ważne

${ }^{1}$ Z. K. Zuziak, Jezzyk urbanistyki i architektoniczne myślenie, "Czasopismo techniczne. Architektura", Wydawnictwo Politechniki Krakowskiej im. T. Kościuszki, Kraków 2008, R.105, z. 6-A, s. 217.

2 J. Kwapisz, J. Kuczyńska-Kwapisz, Orientacja przestrzenna i poruszanie sie niewidomych oraz stabo widzacych, WSiP, Warszawa 1990, s. 5.

${ }_{3}^{3}$ Percepcja przestrzeni to proces, dzięki któremu ludzie i inne organizmy stają się świadomi względnych pozycji ich własnych ciał i przedmiotów wokół nich. Percepcja przestrzeni zapewnia wskazówki, takie jak głębokość i odległość, które są ważne dla ruchu i orientacji w środowisku. Objaśnienie terminu percepcja przestrzeni zostało zaczerpnięte z Encyklopedii Britannica: https://www.britannica. com/topic/space-perception [dostęp: 23.01.2018].

${ }^{4} \mathrm{~K}$. Miler-Zdanowska, Czynniki warunkujace nauczanie orientacji przestrzennej i samodzielnego poruszania się osób $z$ dysfunkcja wzroku, [w:] Tyflopedagogika we wspótczesnej przestrzeni edukacyjno-rehabilitacyjnej, red. K. Czerwińska, M. Paplińska, 
miejsce $\mathrm{w}$ procesie orientowania się $\mathrm{w}$ przestrzeni zajmuje słuch, który jako pierwszy dostarcza niezbędnych informacji o występowaniu w niej obiektów oraz pozwala ustalić, czy słyszany przedmiot/obiekt jest statyczny czy dynamiczny. Z kolei w zakresie odbioru wrażeń kanałem dotykowym duże znaczenie ma dotyk bezpośredni odbierany poprzez kończyny dolne i górne a także dotyk pośredni za pomocą białej, długiej laski. Natomiast wrażenia odbierane poprzez zmysł kinestetyczny i równowagi pozwalają osobie niewidomej na prawidłowe utrzymanie postawy ciała oraz świadome wykonywanie ruchów ciałem i mięśniowe zapamiętywanie pokonywanych odległości. Nieco mniejsze znaczenie dla orientowania się w przestrzeni ma zmysł powonienia ze względu na szybką adaptację do określonych zapachów występujących w otoczeniu.

Poza odbiorem wrażeń zmysłowych w prawidłowym rozwoju orientacji przestrzennej u osób z niepełnosprawnością wzroku mają również znaczenie procesy poznawcze w szczególności uwaga, pamięć, myślenie oraz wyobraźnia przestrzenna. Prawidłowo przebiegające procesy poznawcze pozwalają osobie niewidomej zwiększyć bezpieczeństwo podczas poruszania się poprzez wykrywanie i adekwatne reagowanie na bodźce w otoczeniu oraz zapamiętywanie miejsc. Z kolei prawidłowo rozwinięta wyobraźnia przestrzenna rozumiana jako „zdolność do wytworzenia w umyśle obrazu lub obiektu geometrycznego, zgodnego z jego rzeczywistym kształtem i położeniem" 5 pozwala zrozumieć relacje przestrzenne zachodzące w przestrzeni pomiędzy obiektami oraz wykorzystać tę wiedzę podczas poruszania się. Osoby z niepełnosprawnością wzroku w oparciu o zdobywane podczas przemieszania się doświadczenie, ruch i obserwację wielozmysłową tworzą mapę poznawczą ${ }^{6}$ otacza-

M. Walkiewicz-Krutak, Wydawnictwo Akademii Pedagogiki Specjalnej w Warszawie, Warszawa 2015, s. 296.

${ }^{5}$ E. Sroka-Bizoń, M., Terczyńska., Percepcja widzenia-jak kształtować wyobraźnię przestrzenna, Referat wygłoszony na Proceedings of 19th Conference Geometry Graphics Computer. Ustroń, 25-27 June 2012. Silesian University of Technology, Geometry and Engineering Graphics Centre.

${ }^{6}$ Termin mapa poznawcza stosowany jest $\mathrm{w}$ wielu obszarach współczesnej nauki. Powstaje jako wynik złożonych operacji umysłowych (zapamiętywanie, kodo- 
jącej je przestrzeni. Niezwykle istotnymi elementami w jej tworzeniu są: ścieżki (typowe elementy przestrzeni, korytarze tworzone przez szlaki komunikacyjne, ulice, drogi itp.), węzły (charakterystyczne punkty występujące przeważnie na ścieżkach, w których dochodzi do koncentracji zachowań, np. skrzyżowania ścieżek czy punkty ich zaburzenia), krawędzie (obiekty tworzące przestrzenne bariery, np. mury, granice, ale także ciągi komunikacyjne), okręgi (regiony, czyli większe obszary o jednolitych cechach, np. tereny przemysłowe czy dzielnice mieszkaniowe, handlowe) oraz punkty orientacyjne (landmarki czyli obiekty charakterystyczne, pozwalające orientować się w przestrzeni np. pomniki, budynki lub obiekty zwracające uwage respondenta swoim zastosowaniem, będącym w polu jego zainteresowań) ${ }^{7}$. Dla osób niewidomych to właśnie punkty orientacyjne stanowią bardzo ważny element przestrzeni, który jest stały, zawsze obecny, trudny do ominięcia. To dzięki nim są w stanie ułożyć w pamięci obraz przestrzeni i zweryfikować poprawność swojego przemieszczania się .

Wszystkie wymienione powyżej czynniki, mające znaczenie dla orientowania się w przestrzeni osób z niepełnosprawnością wzro$\mathrm{ku}$, dotyczą przede wszystkim poznawania przestrzeni i tworzenia map mentalnych. Zewnętrzną formą świadczącą o prawidłowym

wanie informacji, przywoływanie informacji i planowanie działań, antycypacja możliwych sytuacji). Odzwierciedla przyjęte strategie realizacji zamierzonych celów i potrzeb w przestrzeni środowiska. Mapa poznawcza „jest stosunkowo stałym, nie podatnym na zmiany sytuacji konstruktem umysłowym” A. Hauziński, Ewolucja pojęcia mapy poznawczej w psychologii. Przegląd badań dotyczących hierarchii planów i celów działania, „Czasopismo Psychologiczne” 2010, Tom 16, Nr 2, s. 285.

7 Podstawowe elementy map mentalnych zostały zaproponowane przez K. Lyncha w: K. Nieścioruk, Kartograficzny obraz map mentalnych przestrzeni miejskiej i jego prezentacja oraz analiza z zastosowaniem narzędzi systemów informacji geograficznej, "Acta Scientarium Polonorum Geodesia et Descriptio Terrarum" 2013, nr 12 (4), s. 28.

${ }^{8} \mathrm{~W}$ literaturze dotyczącej poruszania się osób z niepełnosprawnością wzroku można odnaleźć podział punktów orientacyjnych na dwie grupy: podstawowe (ang. primary landmarks) i drugorzędne (ang. secondary landmarks). W.R. Wiener, R.L. Welsh, B.B. Blasch (red.), Foundations of Orientation and Mobility. Second Editions, AFB Press, New York 1997, s. 42. 
przebiegu tych procesów (percypowania przestrzeni i rozumienia zachodzących w niej stosunków przestrzennych) jest umiejętność opisu przestrzeni a także swobodne poruszanie się w niej. Do opisu otaczającej nas przestrzeni używamy wyrażeń określających relacje przestrzenne. Nabywamy je w toku naszego życia. Rozwojowo jako pierwsze pojawia się rozumienie pojęć przestrzennych, a dopiero nieco później zostaje opanowane ich poprawne używanie. Dlatego też ważne jest, aby pamiętać, iż „dobre rozumienie komunikatów zawierających określenia relacji przestrzennych nie idzie $\mathrm{w}$ parze z właściwym ich stosowaniem w nadawaniu własnych komunikatów przez dziecko"9.

Opisując przestrzeń poprzez określenie własnego położenia oraz lokalizacji innych przedmiotów i relacji zachodzących między nimi, używamy przede wszystkim:

- zaimkowych określeń miejsca, które: „odsyłają do jakiegoś punktu wyznaczonego w przestrzeni, w którym zachodzi akt mowy, lub punktu znanego rozmówcom"10. Zaimkowo-przysłówkowe wyrażenia lokalizujące towarzyszą gestom lub je zastępują, pomagają określić relacje przestrzenne obiektu lub zależności pomiędzy kilkoma obiektami, informują o przemieszczaniu się obiektu (tu, dokąd, skąd, wszędzie, zewsząd, odtąd, dotąd, to tu, to tam itp.);

- przysłówkowych określeń lokatywnych i latywnych, które informują bezpośrednio o kierunku i sąsiedztwie, np. blisko: daleko, wysoko: nisko, na wprost, górą, spodem, bokiem itp.;

- przestrzennych wyrażeń przyimkowych oraz przyimków. Przyimki informują o odległości, np.: przy, koło, obok, opodal, przed, naprzeciw, naprzeciwko, powyżej, poniżej, wnoszą znaczenia dookoloności, np. dokoła, wokoło, wokół, jak również znaczenie liniowości: wzdłuż, w poprzek i lateralności, np. na prawo, na lewo od;

${ }^{9}$ M. Kielar-Turska, Jak pomagać dziecku w poznawaniu świata, Wydawnictwa Szkolne i Pedagogiczne, Warszawa 1992, s. 153.

10 R. Piętkowa, Funkcje wyrażeń werbalizujących relacje przestrzenne (na materiale wspótczesnej poezji polskiej), Katowice 1989, s. 27. 
- słowotwórczych wykładników lokalizacji, które nazywają zbliżenie (przykleić, dobiec, wbić, nalać itp.), oddalanie się (odjechać, wyjść), przemieszczanie (przejść);

- przymiotników, dzięki którym możemy nazwać skomplikowane relacje przestrzenne, informują one o lokalizacji, wymiarze oraz kształtach przedmiotów, np. bliski, daleki, górny, dolny, przedni, mały, okrągły, kwadratowy ${ }^{11}$.

Ponieważ postrzeganie stosunków przestrzennych odbywa się głównie w przestrzeni wizualnej (wzrok umożliwia jednoczesną percepcję wielu obiektów w przestrzeni, zwłaszcza obiektów oddalonych) osoby z niepełnosprawnością wzroku w zakresie nabywania i poprawnego używania wyrazów określających pojęcia przestrzenne mają zazwyczaj trudności ze rozumieniem przymiotników i przysłówków, które odnoszą się do oceny dystansu, wielkości oraz stosunków przestrzennych (np.: daleko - blisko, wysoki - niski itp.) ${ }^{12}$. oraz przyimków ${ }^{13}$ i wyrażeń przyimkowych (pod, nad, na lewo, na prawo, za, przed, między) ${ }^{14}$.

Trudności te najprawdopodobniej nie wynikają $\mathrm{z}$ zaburzeń orientacji przestrzennej, ale powstają na skutek braku możliwości aktualizacji przestrzennej, czyli możliwości wzrokowego śledzenia

${ }^{11}$ Zestawienie to zostało zaczerpnięte z rozprawy doktorskiej A. Guzy, Kompetencja językowa uczniów a wyobraźnia i orientacja przestrzenna. Nieopublikowana rozprawa doktorska, Wydział Filozoficzny, Uniwersytet Śląski, Katowice 2011.

${ }_{12} \mathrm{~T}$. Gałkowski, Trudności rozwojowe u dzieci niewidomych w okresie niemowlęcym, „Przegląd Tyflologiczny” 1975, 1/3, s. 8.

${ }^{13}$ Badania przeprowadzone przez Andersen (1984); Dunlea \& Andersen (1992) oraz Brambringa (2006) za: M. Brambring, Divergent Development of Verbal Skills in Children Who Are Blind or Sighted, "Journal of Visual Impairment \& Blindness" 2007, 101 (12), s. 749-762 wykazały znaczne trudności i różnice w czasie opanowywania przez dzieci niewidome przyimków przestrzennych $\mathrm{w}$, na, lub, pod. Informacje na ten temat można odnaleźć w: M. Brambring, Divergent Development of Verbal Skills in Children Who Are Blind or Sighted, "Journal of Visual Impairment \& Blindness" 2007.

${ }^{14} \mathrm{~K}$. Klimasiński, Rola wyobrażeń przestrzennych w rozwoju myślenia dzieci niewidomych, Wydawnictwo Polskiej Akademii Nauk, Wrocław - Warszawa - Kraków Gdańsk 1977, s. 80. 
zmiany odległości np.: ja - obiekt, wynikającej z wykonywanego ruchu podczas przemieszczania się, a niekiedy także z braku treningu werbalnego polegającego na połączeniu konkretnej relacji przestrzennej z jej nazwą. Jako przyczynę tego typu trudności można także wskazać specyfikę tworzenia obrazu przestrzeni przez osoby z niepełnosprawnością wzroku, która odbywa się głównie poprzez doznania kinestetyczne i dźwiękowe. Element językowy jest dodatkiem, który uzupełnia ten obraz, ale pochodzi od osób widzących.

Zagadnienia dotyczące rozwoju orientacji przestrzennej u osób z niepełnosprawnością wzroku w ciągu ostatnich 30 lat były obiektem zainteresowania różnych grup naukowców, zarówno psychologów, pedagogów, lekarzy. Ponieważ zakres umiejętności składających się na kompetencje orientacji przestrzennej jest szeroki, poszczególni badacze koncentrowali się na wybranych umiejętnościach z zakresu orientacji przestrzennej u osób z dysfunkcją wzroku, np.: na rozwoju świadomości schematu ciała15, wyobraźni przestrzennej ${ }^{16}$, pamięci przestrzennej ${ }^{17}$ itp. Wśród dostępnych w literaturze przedmiotu badań nie odnalazłam prac dotyczących opisu przestrzeni w postaci wypowiedzi słownej, stąd też zganienie to uczyniłam przedmiotem badań empirycznych.

15 Badania przeprowadzone przez badaczy amerykańskich: B.J. Cratty, C. Peterson, J. Harwis, R. Schoner (1960) za: B. J. Cratty, T.A. Sams, The Body-Image of blind children. The Art Report. New York: The American Foundation for the Blind, 1968 oraz na gruncie polskim Władysława Pilecka, (1980) za: W. Pilecka, Kształtowanie się orientacji $w$ schemacie własnego ciała u dzieci niewidomych. Szkoła Specjalna, 1980, nr 3. s. 235.

16 Badania przeprowadzone przez Krzysztofa Klimasińskiego (1977) za: K. Klimasiński, Rola wyobrażeń przestrzennych w rozwoju myślenia dzieci niewidomych, Wydawnictwo Polskiej Akademii Nauk, Wrocław - Warszawa - Kraków - Gdańsk 1977.

17 Badania Susan Millar (1975) oraz Gordany Miletic (1995) za: S. Millar, Special memory by blind and sighted children, "British Journal of Psychology" 1975, 66, 4, s. 449-459; G. Miletic, Perspective taking: Knowledge of Level 1 and Level 2 rules by congenitally blind, low vision, and sighted children, "Journal of Impairment \& Blindness" $1995,89,6$, s. 514-523. 


\section{Metodologia badań}

Celem zaprezentowanych badań jest przedstawienie sposobów opisu przestrzeni przez dzieci niewidome w wieku wczesnoszkolnym oraz ustalenie czynników, które mają wpływa na opanowanie przez nie tej umiejętności. Badanie i analiza wypowiedzi dzieci niewidomych, dotyczących przestrzeni, w której się poruszają było częścią większego projektu badawczego realizowanego w ramach przygotowywania dysertacji doktorskiej pt: „Przestrzeń w działaniu i wypowiedziach dzieci niewidomych w wieku wczesnoszkolnym" pod kierunkiem prof. dr hab. Jadwigi Kuczyńskiej-Kwapisz. Badanie zostało przeprowadzone w roku szkolnym 2013/2014 oraz 2014/2015 w czterech ośrodkach szkolno-wychowawczych dla dzieci z niepełnosprawnością wzroku w Polsce, w których kształcą się niewidome dzieci w normie intelektualnej (Laski k. Warszawy, Kraków, Bydgoszcz, Owińska k. Poznania) oraz w szkołach ogólnodostępnych na terenie województwa mazowieckiego (Płock, Radom). Grupę badawczą stanowiło 50 uczniów niewidomych w wieku od 6 do 12 lat. Kwalifikując dzieci do udziału w badaniach, brano pod uwagę trzy kryteria: niewidzenie w ujęciu funkcjonalnym (dzieci które nie widziały od urodzenia lub straciły możliwości wzrokowe przed 3. rokiem życia), wiek życia (dzieci między 6. a 12. rokiem życia) oraz brak dodatkowych niepełnosprawności (uczniowie w normie intelektualnej, bez dodatkowych problemów ruchowych i zmysłowych). Ze względu na przedmiot, cel oraz charakter badań, dobór badanej próby był doborem celowym. W grupie 50 badanych dzieci niewidomych w wieku wczesnoszkolnym znalazło się 21 dziewczynek (co stanowi 42\% wszystkich badanych dzieci) oraz 29 chłopców (58\% badanych).

W ramach przeprowadzonych badań wykorzystano dwie wiodące metody badawcze: sondaż diagnostyczny i eksperymenty diagnostyczne. $\mathrm{W}$ ramach pierwszej $\mathrm{z}$ nich zastosowano technikę badania dokumentów oraz technikę wywiadu. Analizie poddano dokumenty osobiste uczniów, znajdujące się na terenie specjalnych ośrodków szkolno-wychowawczych dla dzieci z niepełnosprawno- 
ścią wzroku (analiza dokumentacji medycznej, psychologicznej, pedagogicznej). Zastosowana technika pozwoliła na zgromadzenie wstępnych opisowych i ilościowych informacji o poszczególnych uczniach. Natomiast wywiady przeprowadzono z nauczycielami/wychowawcami klas I-VI szkół podstawowych dla uczniów niewidomych i słabowidzących; $\mathrm{z}$ wychowawcami internatowymi lub rodzicami dzieci niewidomych; $z$ nauczycielami orientacji przestrzennej, pracującymi w poszczególnych ośrodkach. Zastosowana technika pozwoliła na zgromadzenie szczegółowych informacji, dotyczących funkcjonowania $\mathrm{w}$ zakresie orientacji przestrzennej poszczególnych dzieci na terenie szkoły, internatu, domu. Drugą zastosowaną metodą były eksperymenty diagnostyczne ${ }^{18}$ (zastosowane techniki: zadania diagnostyczne, obserwacja). Z uwagi na fakt, iż w rozważaniach teoretycznych wskazano na wiodący model rozwoju orientacji przestrzennej $\mathrm{u}$ dzieci (Piagetowska teoria rozwoju orientacji przestrzennej oraz badania postpiagetowskie), wybrano metodę eksperymentów diagnostycznych, utrzymanych w konwencji zadań J. Piageta. Umożliwiła ona ocenę umiejętności z zakresu orientacji przestrzennej oraz wskazanie przyczyn i uwarunkowań tego stanu rzeczy. W badaniach wykorzystano także obserwację $^{19}$ dziecięcych zachowań podczas przeprowadzania zadań diagnostycznych.

${ }^{18}$ Eksperymenty diagnostyczne zostały zastosowane na szeroką skalę przez wybitnego psychologa J. Piageta w badaniach nad dziecięcym umysłem. Na gruncie polskim kontynuatorami tej metody są Anna Szemińska, Zbigniew Semadeni, ale przede wszystkim na dużą skalę Edyta Gruszczyk-Kolczyńska (badania dotyczące orientacji przestrzennej, zdolności matematycznych itd.). Metoda ta jest opiera się na założeniu, iż "eksperyment jest pewną odmianą obserwacji przeprowadzoną w specjalnie zorganizowanych warunkach" M. Łobocki, Metody badań pedagogicznych, Oficyna Wydawnicza „Impuls", Kraków 2000, s. 146.

${ }^{19}$ Zastosowano technikę obserwacji aranżowanej, w której „badający jest organizatorem obserwowanych zdarzeń/zjawisk: wywołuje je, prowokuje ich wystąpienie, a następnie poddaje je obserwacji" w: M. Guzik-Tkacz, Badania diagnostyczne w pedagogice i psychopedagogice, Wydawnictwo Akademickie "Żak”, Warszawa 2011 s. 256. 
Do przeprowadzenia badań posłużyły samodzielnie skonstruowane narzędzia badawcze ${ }^{20}$ : kwestionariusz do badania dokumentów, kwestionariusze wywiadu z nauczycielami, wychowawcami, nauczycielami orientacji przestrzennej; pakiet „Funkcjonalna ocena wybranych umiejętności z zakresu orientacji przestrzennej dla dzieci z niepełnosprawnością wzroku w wieku od 7 do 12 lat", zawierający próby diagnostyczne, arkusze obserwacyjne zachowań dziecka oraz przewodnik skalowy do interpretacji wyników. Jedną z części wspomnianego powyżej pakietu diagnostycznego stanowiło zadanie diagnostyczne o nazwie "Droga”, którego celem było sprawdzenie umiejętności opisywania przestrzeni przez dzieci niewidome. Osoba przeprowadzająca badanie kierowała do każdego dziecka to samo polecenie „Opisz drogę, którą idziesz od drzwi wejściowych szkoły do swojej ławki w klasie. Wymień miejsca, które mijasz; powiedź o skrętach, zwrotach jakie wykonujesz". Dziecko na wykonanie tego zadania miało nieograniczoną ilość czasu, mogło zaczynać od początku jeśli uznało, że o czymś zapomniało $\mathrm{w}$ trakcie opisu drogi. Wypowiedź dziecka była rejestrowana $\mathrm{w}$ postaci zapisu cyfrowego przy użyciu dyktafonu. Następnie dokonano jej odsłuchu i zapisu w formie tekstowej. Uzyskany w ten sposób materiał badawczy, poddano analizie ze względu na używane przez dzieci w opisie: pojęcia przestrzenne, wskazówki i punkty orientacyjne, wyrazy określające następstwo czasowe, inne specyficzne wyrazy.

\section{Analiza i interpretacja wyników badań}

W toku przeprowadzonych analiz ustalono, że dzieci niewidome, opisując znajomą przestrzeń, nazywają kolejno wykonywane

${ }^{20} \mathrm{Z}$ uwagi na fakt, iż na rynku polskim nie ma narzędzi do diagnozowania dziecięcych kompetencji $\mathrm{w}$ zakresie orientacji przestrzennej przeznaczonych dla dzieci z niepełnosprawnością wzroku, skonstruowane zostały narzędzia uwzględniające specyfikę postrzegania pozawzrokowego oraz etapy nabywania umiejętności z zakresu orientacji przestrzennej. 
podczas przemieszczania się czynności, używając czasowników: idę, schodzę, wchodzę, skręcam. Dzieci wymieniały również zlokalizowane na trasie marszu punkty orientacyjne. Podawały nazwy odbieranych przez dotyk stóp i dłoni elementów otoczenia (wzniesienie, kaloryfer itp.), nie wskazując na żadne słuchowe elementy otoczenia ( $w$ opisie żadnego dziecka nie pojawiły się informacje odbierane przez kanał słuchowy).

Tabela 1. Charakterystyka elementów mapy mentalnej $u$ dzieci niewidomych w wieku wczesnoszkolnym.

\begin{tabular}{|l|l|l|}
\hline $\begin{array}{c}\text { Elementy mapy } \\
\text { mentalnej } \\
\text { wg. K. Lyncha }\end{array}$ & \multicolumn{1}{|c|}{$\begin{array}{c}\text { Charakterystyka } \\
\text { poszczególnych elementów } \\
\text { mapy mentalnej }\end{array}$} & $\begin{array}{c}\text { Przykłady poszczegól- } \\
\text { nych elementów map } \\
\text { mentalnych - dzieci } \\
\text { niewidome }\end{array}$ \\
\hline Ścieżki & $\begin{array}{l}\text { typowe elementy przestrzeni, } \\
\text { korytarze tworzone przez szlaki } \\
\text { komunikacyjne }\end{array}$ & korytarz, hol \\
\hline Węzły & $\begin{array}{l}\text { charakterystyczne punkty wy- } \\
\text { stępujące przeważnie na ścież- } \\
\text { kach, w których dochodzi do } \\
\text { koncentracji zachowań, np. } \\
\text { skrzyżowania ścieżek czy punk- } \\
\text { ty ich zaburzenia }\end{array}$ & $\begin{array}{l}\text { klatka schodowa, scho- } \\
\text { dy, ściana }\end{array}$ \\
\hline Krawędzie & $\begin{array}{l}\text { obiekty tworzące przestrzenne } \\
\text { bariery, np. mury, granice, ale } \\
\text { także ciągi komunikacyjne }\end{array}$ & $\begin{array}{l}\text { wnęka w ścianie, ściana } \\
\text { z łazienkami, murek }\end{array}$ \\
\hline Kręgi & $\begin{array}{l}\text { regiony, czyli większe obszary } \\
\text { o jednolitych cechach, np. dziel- } \\
\text { nice mieszkaniowe, handlowe }\end{array}$ & $\begin{array}{l}\text { szatnia, klasa szkolna, } \\
\text { stołówka, pokój nauczy- } \\
\text { cielski, gabinet lekarski }\end{array}$ \\
\hline Punkty orientacyjne & $\begin{array}{l}\text { landmarki czyli obiekty charak- } \\
\text { terystyczne, pozwalające orien- } \\
\text { tować się w przestrzeni np. } \\
\text { pomniki, budynki lub obiekty } \\
\text { zwracające uwagę respondenta } \\
\text { swoim zastosowaniem, będą- } \\
\text { cym w polu jego zainteresowań }\end{array}$ & $\begin{array}{l}\text { gowka, drzwi, dywan, kaloryfer, okno, } \\
\text { grzejnik, poręcz, filar, } \\
\text { kosz na śmieci }\end{array}$ \\
\hline
\end{tabular}


Analiza i charakterystyka poszczególnych elementów otoczenia wykorzystywanych przez dzieci niewidome do tworzenia mapy mentalnej opisywanej przestrzeni została zamieszczona $w$ tabeli 1.

Kolejnym elementem, który pojawił się $\mathrm{w}$ opisie przestrzeni dzieci niewidomych, były nazwy pomieszczeń, które dzieci mijały podczas przemieszania się po opisywanej trasie (np.: sala lekcyjna, kuchenka), nazwy przedmiotów (np.: ławka, kaloryfer, gaśnica), miejsc (np.: klatka schodowa, hol), tak jak gdyby były one ułożone w jednej linii. Dzieci niewidome uczestniczące w badaniu używały podczas tego rodzaju opisu najczęściej wyrazów "potem”, „później". Wyrazy te służą do określania relacji czasowych, natomiast dzieci niewidome używały ich do określania relacji zachodzących $\mathrm{w}$ przestrzeni, czyli postrzegały mijane obiekty $\mathrm{w}$ perspektywie liniowej a nie przestrzennej. Fakt ten pokazuje, iż dzieci precyzyjnie zapamiętały drogę, po której się poruszały, natomiast nie potrafiły opisać relacji zachodzących między mijanymi obiektami czy miejscami. Jako przykład przytoczono wypowiedź Kacpra, lat 9.

Trzeba pójść prosto, potem lekko w lewo, potem schodzi się z góreczki takiej małej, potem prosto po zielonych, potem do chodniczka, potem pierwsza para schodków, potem druga, potem trzeba iść prosto obok sekretariatu szkoty podstawowej, czy jakoś tak, potem wchodzi sie w drzwi szkoty podstawowej $i$ trzeba iść prawa strona i będa drugie drzwi po prawej stronie.

W analizowanych wypowiedziach dzieci niewidomych, zaobserwowano także małe zróżnicowanie używanych przez nie pojęć przestrzennych. Najczęściej pojawiały się pojęcia „w prawo" i „w lewo”, odnoszące się do wykonywanych przez nie podczas marszu zwrotów i skrętów. Rzadziej pojawiały się pojęcia "przede mną”, „naprzeciwko", „przy”. Niekiedy cały opis sporządzony przez dziecko składał się w głównej mierze ze zwrotów i skrętów w prawą lub lewą stronę, bez wskazania konkretnego miejsca wykonania takiego zwrotu. Zapewne tego typu sytuację możemy tłumaczyć wykorzystywaniem podczas przemieszczania się przez osoby niewidome 
zmysłu kinestetycznego i pamięci mięśniowej. Pozwalają one na zapamiętanie czynności, jakie należy wykonać podczas przemieszczania się, bez potrzeby werbalnego określenia miejsca wykonania konkretnego ruchu w przestrzeni. Dla zobrazowania powyższego opisu zamieszczono wypowiedź Juli, 8 lat.

Ide w lewo, potem z szatni w prawo, potem jeszcze raz w lewo i moje drzwi do klasy sa po lewej. Ide i skręcam w lewo, potem prosto $i$ do drzwi i skręcam do holu głównego w lewo.

Natomiast analiza wypowiedzi dzieci niewidomych pod względem używanych pojęć przestrzennych została zaprezentowana w tabeli nr 2.

Tabela 2. Charakterystyka pojęć przestrzennych w wypowiedziach dzieci niewidomych w wieku wczesnoszkolnym

\begin{tabular}{|l|l|l|}
\hline \multicolumn{1}{|c|}{ Pojęcia przestrzenne } & \multicolumn{1}{|c|}{ Osoby widzące } & \multicolumn{1}{c|}{ Dzieci niewidome } \\
\hline $\begin{array}{l}\text { Zaimkowe określenia miejsca, } \\
\text { zaimkowo-przysłówkowe wy- } \\
\text { rażenia lokalizujące }\end{array}$ & $\begin{array}{l}\text { tu, dokąd, skąd, wszędzie, } \\
\text { zewsząd, odtąd, dotąd, to } \\
\text { tu, to tam }\end{array}$ & nie zaobserwowano \\
\hline $\begin{array}{l}\text { Przysłówkowe określenia loka- } \\
\text { tywne i latywne }\end{array}$ & $\begin{array}{l}\text { blisko: daleko, wysoko: } \\
\text { nisko, na wprost, górą, } \\
\text { spodem, bokiem }\end{array}$ & bokiem, na wprost \\
\hline $\begin{array}{l}\text { Przestrzennych wyrażeń przy- } \\
\text { imkowych oraz przyimków. }\end{array}$ & $\begin{array}{l}\text { przy, koło, obok, opodal, } \\
\text { przed, naprzeciw, naprze- } \\
\text { ciwko, powyżej, poniżej, } \\
\text { dokoła, wokoło, wokół, na } \\
\text { prawo, na lewo }\end{array}$ & $\begin{array}{l}\text { obok, przede mną, przy, } \\
\text { naprzeciwko, w prawo, } \\
\text { w lewo, koło, przed }\end{array}$ \\
\hline $\begin{array}{l}\text { Słowotwórczych wykładni- } \\
\text { ków lokalizacji, które nazy- } \\
\text { wają zbliżenie, oddalanie się } \\
\text { lub przemieszczanie }\end{array}$ & $\begin{array}{l}\text { przykleić, dobiec, wbić, } \\
\text { nalać, odjechać, wyjść, } \\
\text { przejść }\end{array}$ & $\begin{array}{l}\text { dochodzę, wchodzę, } \\
\text { schodzę, wychodzę, } \\
\text { przechodzę }\end{array}$ \\
\hline $\begin{array}{l}\text { Przymiotników, dzięki któ- } \\
\text { rym możemy nazwać skompli- } \\
\text { kowane relacje przestrzenne }\end{array}$ & $\begin{array}{l}\text { bliski, daleki, górny, } \\
\text { dolny, przedni, mały, } \\
\text { okrągły, kwadratowy }\end{array}$ & długi, mały \\
\hline
\end{tabular}


W opisie przestrzeni dzieci niewidomych zaobserwowano także używanie słów, które świadczą o nieprecyzyjnym określaniu pokonywanych podczas marszu odległości, np.; „idę kawałeczek”, „kawałek holu”, "troszeczkę w prawo”, „idę trochę”, „idę dłuższy czas" itp. Używanie tego typu określeń, pokazuje, że dla dziecka niewidomego pewną trudnością jest precyzyjne określenie przebytej drogi przy użyciu, miar służących do opisu odległości (metr, centymetr itp.). Wynika to $\mathrm{z}$ faktu braku wzrokowej kontroli otoczenia.

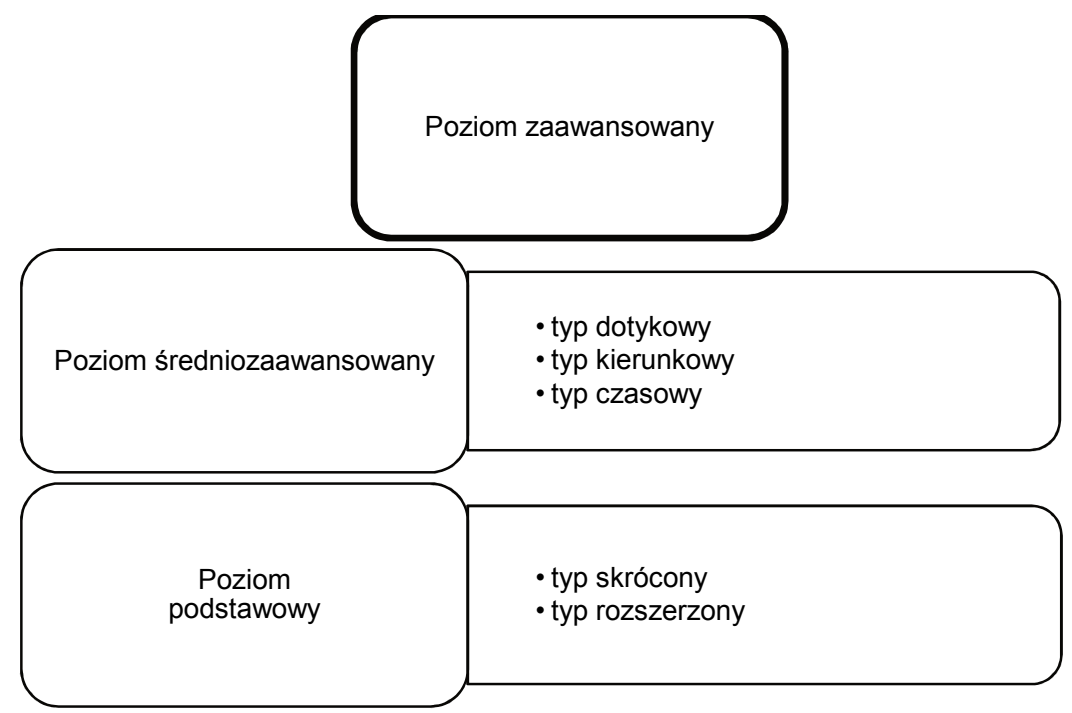

Schemat 1. Poziomy opanowania umiejętności opisu przestrzeni

Źródło: opracowanie własne

Natomiast podczas analizy opisów przestrzeni zaskakujący okazał się fakt, iż dzieci niewidome posługiwały się nazwami kolorów, w odniesieniu do mijanych miejsc, czy obiektów np.: "dochodzę do zielonych schodów”, „wchodzę w pomarańczowy korytarz”, "mijam zieloną klatkę schodową". Mimo braku możliwości 
weryfikacji informacji o kolorach, uczniowie niewidomi przyswoili sobie ich nazwy i używają ich do opisu przestrzeni, aby lepiej móc się komunikować z osobami widzącymi.

$\mathrm{Na}$ podstawie analizy zebranego materiału badawczego, ze względu na stopień opanowania umiejętności opisu przestrzeni, dokonano podziału wypowiedzi badanych dzieci niewidomych na trzy główne poziomy: poziom podstawowy, średniozaawansowany, zaawansowany. W każdym z poziomów wyodrębniono dodatkowo typy opisów. Szczegółowy podział poziomów umiejętności opisu przestrzeni został zaprezentowany na schemacie nr 1.

Wśród badanych dzieci niewidomych aż 46\% dokonało opisu przestrzeni na poziomie podstawowym. Opis ten był chaotyczny, zawierał wybiórcze informacje, pomijał istotne szczegóły. W tej grupie w większości znalazły się dzieci siedmioletnie. Ponad połowa $\mathrm{z}$ nich posługiwała się typem opisu skróconego, czyli takiego, w którym brak było informacji o przestrzeni. Opis nie zawierał pojęć przestrzennych natomiast znalazły się w nim informacje o zwrotach ale bez kierunku ich wykonywania. Pozostała część dzieci siedmioletnich posługiwała się opisem o typie rozszerzonym. Opis ten zawierał dużo informacji o miejscach, wykonywanych zwrotach, punktach informacyjnych, ale nie były one poukładane w logiczną całość. Jako przykład opisu podstawowego - typ skrócony przytoczono wypowiedź Alana, lat 7.

Jade winda wysiadam $z$ windy, no ide sobie prosto i jestem w klasie Ide prosto wsiadam do windy $i$ jade na parter $i$ juz.

Natomiast jako przykład opisu podstawowego typ rozszerzony zamieszczono wypowiedź Hati, lat 7.

Wchodzimy do szatni, wychodze z szatni ide w prawo, potem prosto, a później przy dwóch barierkach w lewo. Wychodzę i idę prosto korytarzem.

W grupie badanych dzieci niewidomych w wieku od 8 do 11 lat dominował opis przestrzeni na poziomie średniozaawansowanym 
(42\% badanych dzieci). Opis ten charakteryzował się występowaniem dużej ilości informacji, które odnosiły się do wskazówek dotykowych, odbieranych za pomocą stóp i dłoni (typ dotykowy) lub był skoncentrowany na wykonywanych podczas poruszania się zwrotach i skrętach (typ kierunkowy) lub odnosił się do mijanych kolejno obiektów i miejsc z użyciem określeń czasowych: potem, później (typ czasowy). Przykłady poszczególnych typów opisów na poziomie średniozaawansowanym zostały zamieszczone poniżej.

Patryk, 8 lat, poziom średniozaawansowany - typ dotykowy

Wychodzę w lewo i idzie się i idzie się i mija się sale Ib, potem się skręca i robi taki zawijas i robi się 13 schodków w dót, taka barierka żeby się za nia zlapać, $i$ tu się skręca $i$ tu się wchodzi i już.

Hubert 9 lat, poziom średniozaawansowany - typ kierunkowy

Wchodze do szkoty, idę w lewo, później w lewo i w prawo, kawatek prosto i później w lewo i w prawo, prosto w lewo i prosto i później dwie pary drzwi mijam i w piate drzwi w prawo.

Anna, 9 lat, poziom średniozaawansowany - typ czasowy

Od grupy to idę prosto, prosto, jeszcze prosto i mijam łazienkę, pózniej prosto i w lewo i potem ide prosto i na zielona klatke schodowa i mijam salę i później jest moja.

Natomiast tylko $12 \%$ wszystkich badanych dzieci niewidomych posługiwało się opisem na poziomie zaawansowanym i były to głównie dzieci jedenastoletnie. Ten typ opisu zawierał zwroty określające relacje przestrzenne między osobami, obiektami $\mathrm{w}$ przestrzeni, miejscami. Zawierał także czasowniki odnoszące się do wykonywanych podczas poruszania się czynności. Opis był spójny, rzeczowy, wyczerpujący. Dla zobrazowania powyższej charakterystyki opisu zamieszczono wypowiedź Wiktorii, lat 10:

Mam klase po lewej stronie, ide korytarzem szkoty podstawowej, wychodze z korytarza, mijam schody na aule, potem skreccam w lewo, 
schodzę zielonymi schodami na parter, po lewej będzie tawka i muszę skręcić w prawo i będzie przede mna portiernia.

\section{Podsumowanie i wnioski}

Na podstawie powyższych danych możemy wnioskować, iż dzieci niewidome rozwijają swoje kompetencje $\mathrm{w}$ zakresie opisu przestrzeni wraz z nabywaniem innych umiejętności z orientacji przestrzennej i są one związane $z$ wiekiem i doświadczeniem gromadzonym przez dzieci. Oceniając poziom opisu przestrzeni dziecka niewidomego, należy pamiętać również o tym, że poza wymienionymi czynnikami niezwykle istotny wpływ w tym zakresie ma także widzący pośrednik (nauczyciel, rodzic, terapeuta itp.). To on uczy opisu niewidome dziecko poprzez własne wypowiedzi, używane słownictwo. Osoba pośrednicząca jest bardzo ważnym czynnikiem, o czym może świadczyć fakt, iż wśród badanych dzieci niewidomych, te, które nie potrafiły dokonać opisu, lub ich opis był szczątkowy, zawsze powoływały się na sytuacje, w której to nauczyciel je prowadzi i nie podaje informacji o otaczającej przestrzeni. W przypadku małego dziecka, które dopiero uczy się interpretowania przestrzeni, zdobywanie informacji słownych jest niezwykle ważne, dopełnia i tłumaczy doznania dotykowe.

Osoby z niepełnosprawnością wzroku pomimo trudności w zakresie poznawania i interpretowania otaczającej je przestrzeni w wyniku gromadzenia codziennych doświadczeń są w stanie przestrzeń zrozumieć i wiedzę tę wykorzystać podczas jej eksplorowania. Czynności te wymagają od nich dużo większego wysiłku i większej ilości czasu niż od osób widzących z uwagi na fakt, iż przestrzeń najłatwiej poznajemy poprzez wzrok i doświadczenie kinestetyczne - ruch. Pomimo innych strategii zdobywania wiedzy o przestrzeni osoby z niepełnosprawnością wzroku są aktywnymi jej uczestnikami oraz potrafią w podobny sposób jak osoby widzące opisywać to, co je otacza. Opis ten jest w wielu aspektach podobny do opisu konstruowanego przez osoby widzące. Osoby niewidome 
mają te same strategie tworzenia map mentalnych służących do tworzenia wyobrażeń umysłowych poznawanej przestrzeni, o czym świadczy występowanie w obu grupach tych samych elementów map poznawczych (ścieżek, węzłów, krawędzi, kręgów oraz punktów orientacyjnych). Tym co różnicuje te dwie grupy jest liczba wystąpień poszczególnych elementów. U osób z niepełnosprawnością wzroku można zaobserwować posługiwanie się większą liczbą punktów orientacyjnych oraz ich jakościowym zróżnicowaniem (landmarki dotykowe, słuchowe, węchowe, termiczne itp.). Zarówno osoby niewidome, jak i widzące do opisu przestrzeni używają w większości tych samych wyrazów (przysłówków, wyrażeń przyimkowych, przyimków, przymiotników itp.). Choć liczba i zakres ich użycia u osób z dysfunkcją wzroku jest uboższy.

Umiejętność tworzenia opisu otaczającej nas przestrzeni jest procesem, który doskonalimy przez całe życie. Zarówno u osób widzących jak i u osób niewidomych proces ten związanym jest z wiekiem i zdobytym doświadczeniem podczas przemieszania się. Dodatkowo u osób z niepełnosprawnością wzroku niezwykle istotne znaczenie pełnią osoby pośredniczące (czyli rodzice, nauczyciele, itp.). Z tego też powodu bardzo ważne jest aby umiejętność tę doskonalić w sposób poprawny, czyli używając precyzyjnych, szczegółowych określeń odnoszących się do opisu relacji przestrzennych.

\section{Bibliografia}

Brambring M., Divergent Development of Verbal Skills in Children Who Are Blind or Sighted, "Journal of Visual Impairment \& Blindness" 2007.

Cratty B.J., Sams T.A., The Body-Image of blind children. The Art Report.: The American Foundation for the Blind, New York 1968.

Encyklopedii Britannica: https://www.britannica.com/topic/space-perception [dostęp: 23.01.2018].

Foundations of Orientation and Mobility.Second Editions, red. Wiener W.R., Welsh R.L., Blasch B.B., AFB Press, New York 1997.

Gałkowski T., Trudności rozwojowe u dzieci niewidomych w okresie niemowlęcym, „Przegląd Tyflologiczny" 1975, 1/3. 
Guzik-Tkacz M., Badania diagnostyczne w pedagogice i psychopedagogice, Wydawnictwo Akademickie „Żak”, Warszawa 2011.

Guzy A., Kompetencja językowa uczniów a wyobraźnia i orientacja przestrzenna. Nieopublikowana rozprawa doktorska, Wydział Filozoficzny, Uniwersytet Śląski, Katowice 2011.

Hauziński A., Ewolucja pojęcia mapy poznawczej w psychologii. Przegląd badań dotyczacych hierarchii planów i celów działania, "Czasopismo Psychologiczne" 2010, Tom 16, Nr 2.

Kielar-Turska M., Jak pomagać dziecku w poznawaniu świata, Wydawnictwa Szkolne i Pedagogiczne, Warszawa 1992.

Klimasiński K., Rola wyobrażeń przestrzennych w rozwoju myślenia dzieci niewidomych. Wydawnictwo PAN, Wrocław - Warszawa - Kraków - Gdańsk 1977.

Kwapisz J., Kuczyńska-Kwapisz J., Orientacja przestrzenna i poruszanie się niewidomych oraz stabo widzacych, WSiP, Warszawa 1990.

Łobocki M., Metody badań pedagogicznych, Oficyna Wydawnicza „Impuls”, Kraków 2000.

Miler-Zdanowska K., Czynniki warunkujące nauczanie orientacji przestrzennej $i$ samodzielnego poruszania się osób z dysfunkcją wzroku, [w:] Tyflopedagogika we współczesnej przestrzeni edukacyjno-rehabilitacyjnej, red. K. Czerwińska, M. Paplińska, M. Walkiewicz-Krutak, Wydawnictwo Akademii Pedagogiki Specjalnej w Warszawie, Warszawa 2015.

Miletic G., Perspective taking: Knowledge of Level 1 and Level 2 rules by congenitally blind, low vision, and sighted children, "Journal of Impairment \& Blindness" 1995, 89,6 .

Millar S., Special memory by blind and sighted children, "British Journal of Psychology" $1975,66,4$.

Millar S., Special representation by blind and sighted children, "Journal of Experimental Child Psychology" 1996, 21, 3.

Nieścioruk K., Kartograficzny obraz map mentalnych przestrzeni miejskiej i jego prezentacja oraz analiza z zastosowaniem narzędzi systemów informacji geograficznej, "Acta Scientarium Polonorum Geodesia et Descriptio Terrarum" 2013, nr 12 (4).

Pilecka W., Ksztattowanie się orientacji w schemacie wtasnego ciała u dzieci niewidomych, „Szkoła Specjalna” 1980, nr 3.

Sroka-Bizoń E., Terczyńska M., Percepcja widzenia - jak ksztattować wyobraźnię przestrzenna. Referat wygłoszony na Proceedings of 19th Conference Geometry Graphics Computer. Ustroń, 25-27 June 2012. Silesian University of Technology, Geometry and Engineering Graphics Centre.

Zuziak Z.K., Język urbanistyki i architektoniczne myślenie, "Czasopismo techniczne. Architektura", Wydawnictwo Politechniki Krakowskiej im. T. Kościuszki, Kraków 2008, R. 105, z. 6-A. 